\title{
Demand for light fuels in Brazil: an approach using spatial panel data models
}

Demanda por combustíveis leves no Brasil: uma abordagem usando modelos espaciais de dados em painel

\begin{abstract}
The need for changes in the current energy matrix is a reality due to the possibility of a shortage of fossil fuels and the environmental damage caused by emissions related to fossil fuel use. The correct prescription of public policies for energy markets depends on the knowledge of demand elasticities. Hence, the aim of this work was to estimate the main determinants of light fuel demands in Brazil. Dynamic and non-dynamic estimators were used, and the results indicated that both demands respond more to changes in gasoline prices than changes in ethanol prices. Therefore, public policies that aim to change consumption patterns should focus on gasoline prices.
\end{abstract}

\section{Keywords}

spatial econometrics, ethanol, gasoline, panel data.

JEL Codes Q41, R15, C21.

\author{
Leonardo C. B. Cardoso (1) \\ Maurício V. L. Bittencourt (2) \\ Alexandre A. Porsse ${ }^{(3)}$ \\ (1) Federal University of Viçosa \\ (2) Federal University of Paraná \\ (3) Federal University of Paraná
}

\section{Resumo}

As mudanças na atual matriz energética são necessárias por conta da futura escassez dos fósseis e pelos danos causados por seu consumo. A correta prescrição de políticas públicas para os mercados de energia necessita do conhecimento das elasticidades da demanda. Por isso, o objetivo deste estudo é estimar os principais determinantes da demanda para o etanol e para a gasolina no Brasil. Estimadores dinâmicos e não dinâmicos foram utilizados es resultados indicam que ambas as demandas respondem mais a mudanças nos preços da gasolina do que a mudanças nos preços do etanol. Por isso, políticas públicas focadas em mudar hábitos de consumo (redução do consumo de gasolina, por exemplo) têm no preço da gasolina um bom instrumento.

\section{Palavras-chave}

econometria especial, etanol, gasolina, dados em painel.

Códigos JEL Q41, R15, C21. 


\section{Introduction}

The need for changes in the current energy matrix is a reality due to both the shortage of oil and the emissions caused by fossil fuel use. Although the news has indicated otherwise, more than $85 \%$ of the world's primary energy consumption still comes from fossil fuels and only $10 \%$ of primary energy is provided by renewable sources (BP, 2018). Even though the reserves-to-production ratio $(\mathrm{R} / \mathrm{P})$ has increased in the last years, ${ }^{1}$ in the medium and long terms, matrix diversity is still necessary.

This first paragraph could have been written ten or twenty years ago with little adjustment to the percentages, so why did the new technologies take so long to attain larger shares of the energy market? Economic viability is the main problem of most energy alternatives. Some may present technology viability; however, their production is not economically viable due to high costs. At this point, Brazilian ethanol is already economically viable and used extensively in some states in Brazil.

This is possible due to institutional arrangements including mandates and subsidies (CARDOSO et al., 2019) and a long tradition in research and private and public investments. Other reasons to consider Brazilian ethanol from sugarcane in the medium term are its advantages over other crops used for ethanol production: a better fossil energy balance, reduced $\mathrm{CO} 2$ emissions in comparison with gasoline and lower land intensity (GOLDEMBERG and GUARDABASSI, 2009; NARDY and GURGEL, 2013). Despite all these advantages, in many Brazilian states, the ethanol demand is constrained. This is due to large differences in relative prices across states (see Figure-1). In some of them, for example Roraima (RO), Amapá (AP) and Pará (PA), the relative price indicates that ethanol should be bought in less than $15 \%$ of months.

These differences, shown in Figure 1, indicate that the price ratio between ethanol and gasoline is not aleatory: space plays a role - and the use of a spatial econometrics framework to estimate the ethanol and gasoline demands in Brazil can be a solution. This choice will also allow the

1 The ratio between the proved reserves and the annual consumption of oil indicates how long the remaining resources will last, based on constant prices and technology. The evolution of the ratio responds to increasing oil prices, technology changes and new discoveries of resources. Data from BP $(2013,2018)$ show that this ratio has increased from approximately 40 years (2005) to 52 years (2013), with a slight decrease in the last 4 years to 50.2 years (2017). 
cross-section dependence (CD) in panel data to be controlled, which is a problem that the literature regarding fuels in Brazil has usually neglected.

Figure 1 Ratio between ethanol and gasoline prices

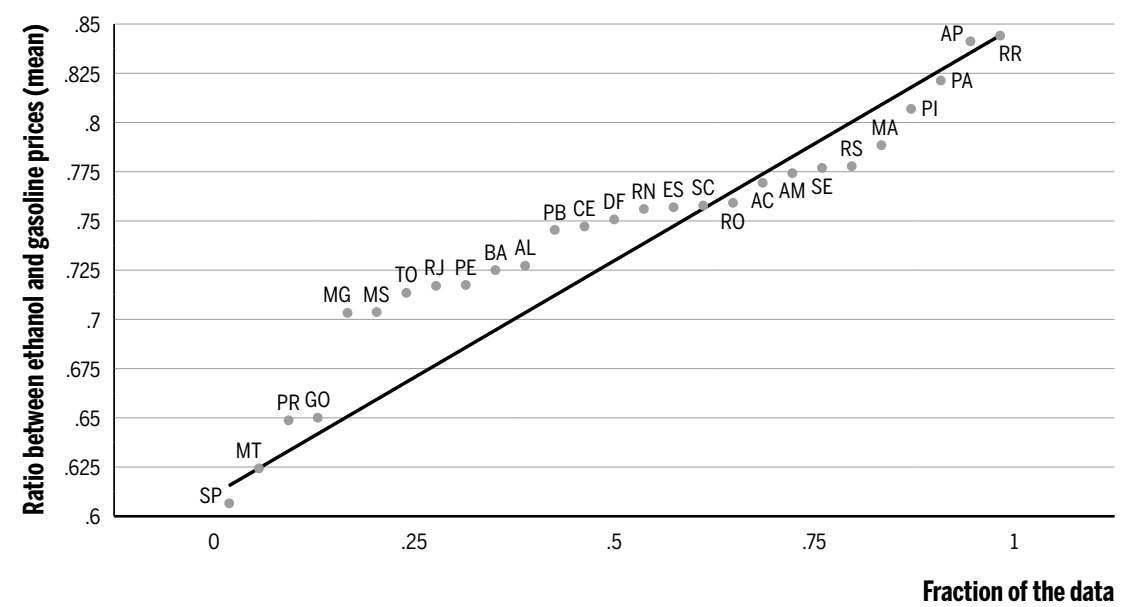

Source: Data from ANP.

In addition to the common variables used to estimate light fuel demands (price and income), in the Brazilian market, ${ }^{2}$ it is necessary to include the prices of the main alternative fuels (the ethanol price for the gasoline demand and the gasoline price for the ethanol demand). An extra variable named "fleet" will therefore be added to consider the possible effects that an increase in the number of vehicles might have on the demand. Spatial non-dynamic and dynamic models will be estimated. For light fuel demands, dynamic models present some advantages: they add information for computing long- and short-run responses.

After this introduction, the paper presents a literature review about light fuels, followed by a section on the Brazilian market. Then, a methodology-related section explains the spatial models and the data set. Finally, the last two sections are dedicated to the results, discussion and conclusions.

2 In 2003, flex-fuel cars were introduced into the Brazilian market, which explains the need to include own prices and their main substitutes in the estimates of the demand for light fuels in Brazil. 


\section{Demand for light fuels}

A large number of studies worldwide dealing with the demand for light fuels have indicated gasoline as an inelastic good in the short and long runs, with long-run elasticity being higher than short-run elasticity. Fuels are considered to be "essential goods" in the short run, but the probability of substitution increases in the long run. The light fuel demand has invariably been modelled using price and income as explanatory variables (possible proxies for income are electricity consumption, industrial production and the GDP, as in RODRIGUES and BACCHI, 2016; RODRIGUES et al., 2018). Some studies, such as those by BURNQUIST and BACCHI (2002), CHEUNG and THOMSON (2004) and RAMANATHAN (1999), did not use other variables and estimated the demand using price and income only. Other common controls are the vehicles' characteristics, such as efficiency, the price of new vehicles, credit availability (RODRIGUES and BACCHI, 2016) and the stock of vehicles (RODRIGUES et al., 2018).

Table A (Appendix) presents many studies regarding the demand for light fuels in Brazil and other countries. The high variation among the estimated elasticities could be due to the models employed by the studies (BASSO and OUM, 2007), including the choice between static and dynamic models (BRONS et al., 2008; ESPEY, 1998), the data types used for the estimation (time series, cross-sectional or panel data) and the interval of data (monthly, quarterly or annual) (GOODWIN et al., 2004).

A large range of econometric techniques are used to estimate light fuels' demand. A survey by DAHL and STERNER (1991)3 presented estimations using time series, two- and three-stage least squares, instrumental variables, panel data and other approaches. The range of results for price elasticity was $(-0.12 ;-0.44)$ in the short run and $(-0.23 ;-1.05)$ in the long run. The range of income elasticity was $(0.14 ; 0.58)$ in the short run and $(0.68 ; 1.31)$ in the long run. Another comprehensive survey is that by HUNTINGTON et al. (2019), which emphasized studies published after 2000, paying attention to the long-run responses to changes in income and prices. Most of the surveyed studies have shown that the price and income elasticities for liquid fuels are generally less than unity for many countries and sectors. Long-run income elasticity, however, can range widely 3 DAHL and STERNER (1991) compared more than 100 studies about the gasoline demand. Another important survey can be found in ESPEY (1998). 
by country between 0.24 and 1.75 while averaging 0.94 for all countries.

In the Brazilian market, BURNQUIST and BACCHI (2002) estimated the demand from 1973 to 1998 using time series (Table A). More recently, NAPPO (2007) used a co-integrated time series to model the gasoline demand. The gasoline price, income (per capita GDP), ethanol price and a dummy associated with the gasoline price starting in 2003 were used as explanatory variables. The results indicated that flex-fuel cars contributed to making the gasoline demand more elastic after 2003. The short-run elasticities estimated were -0.20 (before 2003) and -0.33 (after 2003).

SERIGATI et al. (2010) estimated the Brazilian ethanol demand and the sugar and ethanol supply, simultaneously, using 3SLS. The addition of sugar demand was justified due to the possibility of shifting production from sugar to ethanol and vice versa. The results indicated that the demand for ethanol is price elastic, with elasticity around -1.2 (before 2003) and -2.0 (after 2003). The cross-price elasticity increased from 1.3 to 2.2 (all results for the short run).

RANDOW et al. (2010) estimated the long-run ethanol demand using co-integrated time series models. The variables used to estimate ethanol consumption were the ethanol price, gasoline price and GDP (income proxy). The results indicated very elastic long-run demands related to prices, with elasticities of -11.26 (price elasticity) and 12.79 (cross-price elasticity). The estimated income elasticity was 0.46 .

Also making use of co-integrated time series models for the Brazilian ethanol market, FARINA et al. (2010) analysed the period from July 2001 to August 2009. Their results showed a price elasticity of -1.23 and a cross elasticity of 1.45 , both for the short run.

CARDOSO and BITTENCOURT (2012) and SANTOS (2013) estimated the Brazilian ethanol demand in the long and short runs using co-integrated panel data models. CARDOSO and BITTENCOURT's (2012) study resulted in ethanol price elasticities of -1.42 (short run) and -3.30 (long run), while SANTOS's (2013) elasticity estimates with respect to the ethanol price were around -1.52 (short run) and -8.45 (long run). Regarding the long-run elasticities, SANTOS (2013) indicated that the reported results were likely to be overestimated.

Although intensive research has been carried out, only one conference paper has reported the use of spatial econometrics to assess the Brazilian market. It was co-authored by SANTOS and FARIA (2012), and the 
ethanol and gasoline demands were estimated on a quarterly basis. The explanatory variables were the ethanol price, gasoline price and service trade tax as an income proxy. Here the dynamic estimators were used to aggregate short-run information for further analysis.

ALMEIDA et al. (2016) used a linear approximation almost ideal demand system (LA-AIDS) with quarterly data from 2001 to 2015 to estimate the Marshallian and Hicksian demands for the state of Pernambuco (PE), Brazil, for ethanol, gasoline and diesel. Using seemingly unrelated regressions (SURs), the results were similar to the elasticities reported in the literature, with an inelastic price demand for gasoline and diesel, and close to unitary elasticity for the Marshallian ethanol price elasticity.

Using a vector autoregression (VAR) model, RODRIGUES and BACCHI (2016) identified the main determinants of the demand for fuels used by the light-vehicle fleet in Brazil between 2003 and 2013. The results showed that the income and price elasticities are not different from the estimates reported by the literature. The novelty was the importance of credit and car prices to the demand for transportation in Brazil.

In a recent study about the demand for vehicle fuels in Brazil, RODRIGUES et al. (2018) analysed the role of the asymmetric price response (APR) and underlying energy demand trend (UEDT) in the demand for automotive fuels in Brazil for the period 2001-2016. The authors determined that consumer responses to changes in prices are not linear, with high substitutability between gasoline and ethanol, and the demand for ethanol is more price elastic than the demand for gasoline in the short and long runs.

Finally, CARDOSO et al. (2019) estimated the own-price, cross-price and income elasticities of the demand for ethanol and gasoline for Brazil between 2001 and 2014. They used a novel instrumental variable approach to control for endogeneity between the supply and the demand, which is based on wholesale prices for gasoline, ethanol and diesel from non-adjacent states, to construct the instrumental variables. This study took into account regional and spatial features of the fuel market along with the role of flex-fuel cars. The results showed that, after the introduction of flex-fuel cars, the own-price elasticities for gasoline and ethanol increased.

Other recent studies have investigated other dimensions of the fuel market in Brazil. SALVINI et al. (2017), for instance, investigated price asymmetry in the state of Sao Paulo (SP) for ethanol and gasoline. The results favoured the existence of price asymmetry for both fuels from the 
wholesale to the retail market in the short run. Increases in the wholesale prices imply larger increases for the consumers.

\section{Brazilian market of fuels}

The recent history of light fuels in Brazil presents two relevant events: a) the Petroleum Law (Law 9.478/97), which broke the state monopoly in the oil production; b) the introduction of flex-fuel cars in 2003, allowing consumers to choose between ethanol and gasoline on every visit to the gas station to fill up the vehicle.

Ethanol and gasoline are not evenly consumed throughout the country. The total consumption of ethanol in relation to the total consumption of gasoline in Brazil ${ }^{4}$ (Figure 2, dashed line) during our sample period is 0.23 on average. However, the same variable by state ranges from values around 0.5 in São Paulo to less than 0.05 in Acre and Tocantins. If we look at the more recent values in São Paulo (dark light), ethanol has achieved the same market share as gasoline (relative consumption $=1$ ).

\section{Figure 2 Relative consumption, ethanol by gasoline}

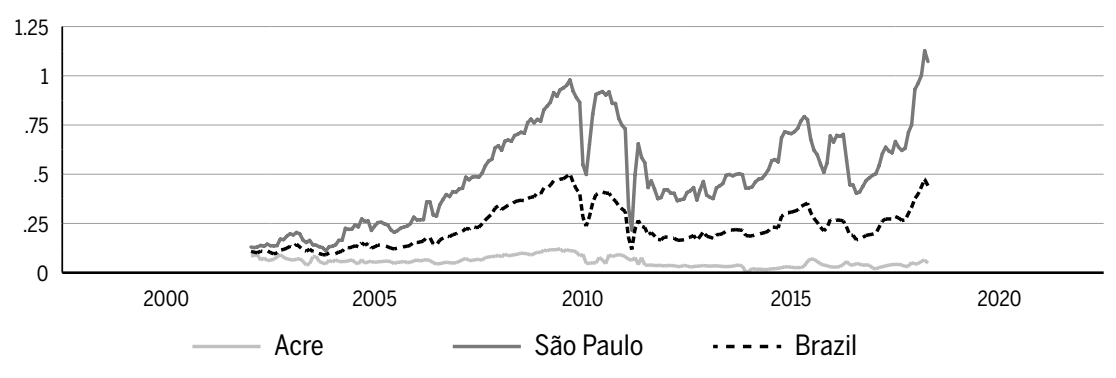

Source: Data from ANP.

Figure 3 (a) shows the mean of the relative consumption of ethanol by gasoline plotted by state - the relative shade indicates the intensity of the variable, with the darkest shades representing the states where the relative consumption of ethanol is lower. These differences in relative consumption are basically the effect of the relative price between ethanol and gasoline 4 Which from now on we will call only relative consumption. This measure uses consumption in barrels of oil equivalent, so the differences in energy content are already controlled. 
(Figure $3(b))$. In this figure, we plot the proportion of time for which ethanol is more price competitive than gasoline during the entire sample period by state. This dummy variable is 1 if the ratio of the ethanol price to the gasoline price is lower than 0.7, which is the reference to control for energy content differences between ethanol and gasoline in Brazil, and 0 otherwise.

Figure 3 The relative consumption of ethanol by state (a) and The proportion of time or which it is worthwhile for fl ex-fuel car owners to buy ethanol rather than gasoline (b)

(a)

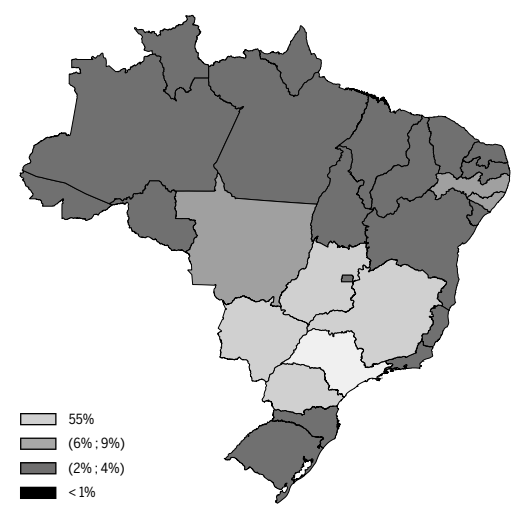

(b)

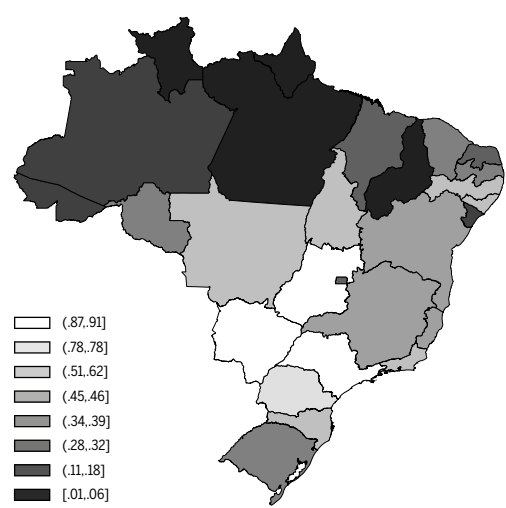

Source: Data from ANP.

These two figures indicate that space plays an important role in the Brazilian fuel market, and the differences are explained mainly by prices. Ethanol's lack of competitiveness in some states can open an entire research agenda, including logistical bottlenecks, sugarcane plantations and others as possible answers.

\section{Data}

Balanced panel data from July 2001 to November 2018 on a monthly basis at the state level will be used. The panel contains a total of 5,643 observations (209 months $\times 27$ states).

The quantities in the data set are of hydrated ethanol (Qeta) and gas- 
oline-C (Qgas), which are sold at gas stations. ${ }^{5}$ Gasoline prices $(P g)$ and ethanol prices $(\mathrm{Pe})$ are the monthly weighted averages of consumer prices. The income proxy is the amount of state tax on the circulation of goods and services (ICMS, acronym in Portuguese) from the Ministry of Finance. The correlation between the gross domestic product and the ICMS in Brazil for our sample is larger than 0.99 , indicating the quality of this proxy.

The variable Fleet-e corresponds to the total number of vehicles that used ethanol along with flex-fuel vehicles. It will be used for the ethanol demand estimation. Fleet- $g$ is the total number of vehicles that used gasoline plus the flex-fuel vehicles, and it will be used for the gasoline demand estimation. The fleet variables are constructed from the database of the National Department of Transportation (Denatran, acronym in Portuguese).

Income and prices are the real variables adjusted using the monthly growth of the consumer price index from the Brazilian Institute of Geography and Statistics (IPCA, acronym in Portuguese), based on 1 in $2001 \mathrm{~m} 7$. Table 2 summarizes the data set statistics.

Table 1 Summary statistics

\begin{tabular}{lrrrrrr}
\hline Variable & Obs. & Mean & S. Deviation & Min. & Max. \\
\hline LnPe & 5,643 & 0.125 & 0.135 & -0.549 & 0.573 \\
\hline LnPg & 5,643 & 0.433 & 0.109 & 0.190 & 0.748 \\
\hline LnIncome & 5,643 & 12.17 & 1.278 & 8.906 & 15.80 \\
\hline LnQeta & 5,643 & 9.941 & 1.887 & 3.611 & 15.12 \\
\hline LnQgas & 5,643 & 12.47 & 1.181 & 8.628 & 15.50 \\
\hline LnFrota-e & 5,643 & 12.79 & 1.560 & 8.693 & 16.73 \\
\hline LnFleet-g & 5,643 & 13.64 & 1.355 & 10.07 & 17.06 \\
\hline
\end{tabular}

Source: ANP, IBGE and Denatran.

Note: Data are in logarithmic form.

\section{Methodology: spatial models and empirical strategy}

Estimating a model using panel data is indicated when there is heterogeneity among individuals (states in this case) - individual effects play an 5 Data are available from the System of Price Research of the Brazilian Agency of Fuel, Biofuel and Natural Gas (ANP). 
important role in the estimations. However, panel estimators also assume that cross-sections are independent from each other.

According to ALMEIDA (2012, p. 109), it is possible to test spatial effects using a scatter diagram of Moran from spatial lagged residuals. Unfortunately, it works with the alternative hypothesis that there is no spatial dependence on the way in which W (the neighbourhood matrix) is specified. In addition, it does not mean that there is no spatial dependence at all, but accepting the alternative does not guarantee the absence of spatial effects. Hence, while working with panel data, it is more appropriate to use some group-wise tests, so the BREUSCH-PAGAN (1980) test will be used here. ${ }^{6}$

The literature presents a possible solution whenever $\mathrm{CD}$ is confirmed. A way of handling the problem is to use estimators consistent with CD, GLS with correction to CD and AR(1) residuals or the PRAIS-WINSTEN (1954) estimator, for example. ${ }^{7}$ Another possibility is to use the spatial econometric approach, adding spatial matrices to the model to capture these spatial effects (ALMEIDA, 2012; ANSELIN et al., 2008; SANTOS and FARIA, 2012). The spatial effects can be included in the spatial lags of the dependent variable $(\mathrm{Y})$, in the explanatory variables $(\mathrm{X})$ and/or in the error term $(\varepsilon)$. Using a basic econometric model:

$$
Y=X \beta+\varepsilon \sim \operatorname{Normal}\left(0, \sigma^{2} I_{n}\right)
$$

Adding the spatial lags to the model (1), we have:

$$
Y=\rho W_{1} Y+X \beta+\tau W_{3} X+\epsilon
$$

where:

$$
\in=\lambda W_{2} \in+\varepsilon
$$

Adding all the spatial lags, the complete model is given by:

$$
Y=\rho W_{1} Y+X \beta+\tau W_{2} X+\lambda W_{3} \in+\varepsilon
$$


In equation (4), W1, W2 and W3 are different spatial matrices, but it is possible to consider them to be equal. Depending on which parameters are equal to zero $(\tau, \lambda$ and/or $\rho),{ }^{8}$ in equation (4) we can have different spatial models. Table 2 presents some of these models.

Table 2 Selected types of spatial models

\begin{tabular}{lrrr}
\hline Models & $\tau$ & $\lambda$ & $\rho$ \\
\hline Spatial Lagged Model (SAR) & $\neq 0$ & 0 & 0 \\
\hline Spatial Autoregressive Cross Model (SLX) & 0 & $\neq 0$ & 0 \\
\hline Spatial Autoregressive Error Model (SEM) & 0 & 0 & $\neq 0$ \\
\hline Spatial Durbin Model (SDM) & $\neq 0$ & $\neq 0$ & 0 \\
\hline Spatial Durbin Error Model (SDEM) & 0 & $\neq 0$ & $\neq 0$ \\
\hline Spatial Lagged Error Model (SAC) & $\neq 0$ & 0 & $\neq 0$ \\
\hline General Spatial Model (GSM) & $\neq 0$ & $\neq 0$ & $\neq 0$ \\
\hline
\end{tabular}

General equation: $Y=\rho W_{1} Y+X \beta+\tau W_{2} X+\lambda W_{3} \in+\varepsilon$.

Source: Authors, based on ALMEIDA (2012, p. 179).

The spatial lags of the dependent variable indicate that the consumption in state (i) is affected by the consumption in state (j). The spatial lags of the explanatory variables indicate that the determinants of consumption in state (i) can be affected by the explanatory variables of state (j). In addition, the spatial lags are used when the error terms across spatial units are correlated, usually indicating an omitted variable problem.

Using our variables and including spatial matrices, the equations for the ethanol and gasoline demand are:

$$
\begin{aligned}
& \text { Qeth }_{i t}=\beta_{0}+\beta_{1^{*}} P e_{i t}+\beta_{2^{*}} \text { Pg }_{i t}+\beta_{3^{*}} \operatorname{Inc}_{i t}+\beta_{4^{*}} \text { Fleet }_{i t}+\rho W_{\text {Qeth }}+ \\
& +\tau W\left(P e_{i t}+P g_{i t}+\operatorname{Inc}_{i t}+\text { Fleet }_{i t}\right)+\varepsilon_{i t} \\
& \operatorname{Qgas}_{i t}=\beta_{0}+\beta_{1^{*}} \text { Pg }_{i t}+\beta_{2^{*}} \text { Pet }_{i t}+\beta_{3^{*}} \text { Inc }_{i t}+\beta_{4^{*}} \text { Fleet }_{i t}+\rho W Q g a s_{i t}+ \\
& +\tau W\left(P e_{i t}+P g_{i t}+\text { Inc }_{i t}+\text { Fleet }_{i t}\right)+\varepsilon_{i t}
\end{aligned}
$$

Equations (5) and (6) are used in the SAR and SDM models, and in both

8 It is also possible to have a range of models if spatial effects are considered, associated with an average spatial moving error. For more information, see ALMEIDA (2012) and FINGLETON (2008). 
of them the marginal effects represent long-run effects, ${ }^{9}$ as they do not provide short-run parameters. However, there is economic relevance to knowing both long- and short-run elasticities. Hence, in addition to the SAR and SDM models, a dynamic panel estimation is proposed here through the use of the HAN and PHILLIPS (2010) estimator. In a dynamic specification, the model is represented by:

$$
Y_{t}=\varphi Y_{t-1}+\rho W Y_{t}+\beta X_{t}+\tau W X_{t}+\varepsilon
$$

Rearranging the equation, we obtain:

$$
Y_{t}=\left(\varphi Y_{t-1}+\beta X_{t}+W X_{t}+\tau W X_{t}+\varepsilon\right) \cdot\left(I_{n}-\rho W\right)^{-1}
$$

This specification allows us to divide the effects between the short and the long run and between direct and indirect effects. ${ }^{10}$ Marginal effects are calculated from a matrix with partial derivatives of $Y$ with respect to the explanatory variable of interest, ${ }^{11}$ which is called Matrix $A$ here.

$$
\frac{\partial Y_{t}}{\partial X_{t}}=\left[\left(I_{n}-\rho W\right)^{-1} \cdot \beta\right]+\left[\left(I_{n}-\rho W\right)^{-1} \cdot \tau\right]=\text { Matrix } A
$$

The total marginal effects are the sum of the indirect and direct effects, and they are calculated using the average of non-zero elements of Matrix A (Equation 9). The mean of the matrix trace gives the direct short-run effects, while the sum of the remaining non-zero elements gives the average indirect effects. If the specified model is an SAR, the parameter $\tau$ is zero and Matrix A is simplified, being represented only by its first term $\left[\left(I_{n}-\rho W\right)^{-1} \cdot \beta\right]$

Differentiation between short- and long-run parameters is made through the $\varphi$ parameter (Equations 7 and 8 ), ${ }^{12}$ which represents the adjustment speed. A low $\varphi$ represents a high adjustment speed, and the short-and long-run parameters will be close. Equation (10) below shows

9 SAR and SDM consider adjusting up to the point of a new steady state, which means that these models can be interpreted as long-run models (LESAGE and PACE, 2011).

10 Indirect effects are also called spatial spillovers. In our case, indirect effects are part of the variation caused by other regions.

11 It is important to note that $\beta$ is a matrix of parameters; hence, for each explanatory variable " $k$ ", one marginal-effect matrix is constructed.

12 The parameter $\varphi$ is constrained to be smaller than 1 to guarantee model stability. 
the long-run impact matrix:

$$
\frac{\partial Y_{t+T}}{\partial X_{t}}=\left[\left(I_{n}-\rho W-\varphi W\right)^{-1} \cdot \beta\right]+\left[\left(I_{n}-\rho W-\varphi W\right)^{-1} \cdot \tau\right]=\text { Matrix } B
$$

As in the short run, the long-run effects can be differentiated between direct and indirect effects, and they are calculated using the same process. It is clear that SAR models have parameter $\tau$ equal to zero, which means that the ratio between direct and indirect effects is the same for all the explanatory variables. SDM models, however, do not present this limitation, which is the reason why, for each explanatory variable, these ratios might be different (DEBARSY et al., 2012; ELHORST, 2012; LESAGE and PACE, 2011).

Concerning the introduction of a spatial weights matrix $W$, many economists are "skeptical, puzzled, or both" and argue that it is applied in a "mechanical fashion" without theoretical justification (CORRADO and FINGLETON, 2012, pp. 210 and 211). Secondly, critics of spatial econometrics have claimed that spatial lagged variables are inputted into models just because of the significance level, without a hard decision criterion. Other usual comments have concerned sensitivity to the choice of weight matrix (W). ARBIA and FINGLETON and ARBIA (2008) highlighted the relevance of this arbitrary decision with respect to the model structure and its consequences for the model results. Hence, we will run the regressions and change $\mathrm{W}$ to determine whether our particular study presents substantial sensitivity to the $\mathrm{W}$ choice.

\section{Results and discussion}

Pesaran's CD test for each variable (ethanol and gasoline prices, income and fleet-g and fleet-e) indicates cross-sectional dependence (CD) for all the variables and for the OLS residuals. The Breusch-Pagan test (BP) is carried out; however, the results remain the same. To correct the $\mathrm{CD}$, a row standardized queen matrix (W) is adopted for the spatial models and a GLS with $\mathrm{AR}(1)$ and CD corrections is estimated. For comparison purposes, an OLS is estimated. All the spatial models estimated initially use the same queen standardized matrix, but, at the end of this section, we relax it, performing the same estimator using different $\mathrm{W}$ matrices. 
Table 3 reports the estimated parameters for the ethanol demand. The short-run parameters are estimated using OLS, GLS and HP, while the long-run parameters are estimated using the SAR, SDM and HP estimators.

Table 3 Estimates for the ethanol demand

\begin{tabular}{|c|c|c|c|c|c|c|c|c|}
\hline & (1) & (2) & (3) & (4) & (5) & (6) & (7) & (8) \\
\hline & OLS & GLS & SAR-FE & SAR-RE & SDM-FE & SDM-RE & HP-SAR & HP-SDM \\
\hline$\Phi\left(Y_{t-1}\right)$ & & & & & & & $\begin{array}{r}0.533^{* * *} \\
(7.53)\end{array}$ & $\begin{array}{r}0.501^{* * *} \\
(7.87)\end{array}$ \\
\hline $\mathrm{LnPe}$ & $\begin{array}{r}-4.998^{* * *} \\
(-70.38)\end{array}$ & $\begin{array}{r}-2.341^{* * *} \\
(-38.61)\end{array}$ & $\begin{array}{r}-2.965^{* * *} \\
(-41.63)\end{array}$ & $\begin{array}{r}-2.965^{* * * *} \\
(-41.91)\end{array}$ & $\begin{array}{r}-3.039 * * * \\
(-32.52)\end{array}$ & $\begin{array}{r}-3.039 * * * * \\
(-32.95)\end{array}$ & $\begin{array}{r}-3.025 * * * * \\
(-41.25)\end{array}$ & $\begin{array}{r}-2.583^{* * *} \\
(-28.68)\end{array}$ \\
\hline LnPg & $\begin{array}{r}3.870^{* * *} \\
(43.32)\end{array}$ & $\begin{array}{r}2.568^{* * *} \\
(27.14)\end{array}$ & $\begin{array}{r}3.598^{* * * *} \\
(35.84)\end{array}$ & $\begin{array}{r}3.597^{* * *} \\
(36.45)\end{array}$ & $\begin{array}{r}5.594^{* * *} \\
(35.53)\end{array}$ & $\begin{array}{r}5.591 * * * \\
(35.50)\end{array}$ & $\begin{array}{r}3.404^{* * *} \\
(33.27)\end{array}$ & $\begin{array}{r}3.426^{* * *} \\
(25.64)\end{array}$ \\
\hline LnFleet & $\begin{array}{r}0.995 * * * \\
(39.18) \\
\end{array}$ & $\begin{array}{r}0.896 * * \\
(32.03) \\
\end{array}$ & $\begin{array}{r}0.908^{* * *} \\
(29.14)\end{array}$ & $\begin{array}{r}0.909^{* * *} \\
(29.16)\end{array}$ & $\begin{array}{r}1.218^{* * *} \\
(23.07)\end{array}$ & $\begin{array}{r}1.229 * * * \\
(24.98)\end{array}$ & $\begin{array}{r}0.972^{* * *} \\
(33.07)\end{array}$ & $\begin{array}{r}1.306^{* * *} \\
(37.82)\end{array}$ \\
\hline LnIncome & $\begin{array}{r}0.145^{* * *} \\
(5.70)\end{array}$ & $\begin{array}{r}0.184^{* * *} \\
(9.25)\end{array}$ & $\begin{array}{r}0.233^{* * *} \\
(5.18)\end{array}$ & $\begin{array}{r}0.234^{* * *} \\
(5.34)\end{array}$ & $\begin{array}{r}-0.0170 \\
(-0.36) \\
\end{array}$ & $\begin{array}{r}-0.00746 \\
(-0.16)\end{array}$ & $\begin{array}{r}0.262^{* * *} \\
(8.15)\end{array}$ & $\begin{array}{r}0.162^{* * *} \\
(4.60)\end{array}$ \\
\hline Const & $\begin{array}{r}-6.640 * * * \\
(-53.77)\end{array}$ & $\begin{array}{r}-5.4111^{* * *} \\
(-16.65)\end{array}$ & & $\begin{array}{r}-10.30 * * * \\
(-27.82)\end{array}$ & & $\begin{array}{r}-7.551^{* * *} \\
(-15.94)\end{array}$ & $\begin{array}{r}-4.204^{* * *} \\
(-27.50)\end{array}$ & $\begin{array}{r}-5.409 * * * \\
(-31.36)\end{array}$ \\
\hline$\rho$ & & & $\begin{array}{r}0.368^{* * *} \\
(34.60)\end{array}$ & $\begin{array}{r}0.364^{* * *} \\
(34.24)\end{array}$ & $\begin{array}{r}0.453^{* * *} \\
(38.17)\end{array}$ & $\begin{array}{r}0.453^{* * * *} \\
(38.25)\end{array}$ & $\begin{array}{r}0.032 * * * \\
(15.20)\end{array}$ & \\
\hline$\tau$ & & & & & & & & \\
\hline LnPe & & & & & $\begin{array}{r}0.976^{* * *} \\
(8.55) \\
\end{array}$ & $\begin{array}{r}0.995^{* * *} \\
(8.79) \\
\end{array}$ & & $\begin{array}{r}-0.271^{* * *} \\
(-9.73)\end{array}$ \\
\hline $\operatorname{LnPg}$ & & & & & $\begin{array}{r}-3.439^{* * *} \\
(-18.38)\end{array}$ & $\begin{array}{r}-3.485^{* * * *} \\
(-18.70)\end{array}$ & & $\begin{array}{r}0.109^{* * *} \\
(3.29)\end{array}$ \\
\hline LnFleet & & & & & $\begin{array}{r}-0.780^{* * *} \\
(-12.97)\end{array}$ & $\begin{array}{r}-0.787^{* * * *} \\
(-13.83)\end{array}$ & & $\begin{array}{r}-0.107^{* * *} \\
(-10.09)\end{array}$ \\
\hline Lnlncome & & & & & $\begin{array}{r}0.557^{* * *} \\
(9.04)\end{array}$ & $\begin{array}{r}0.519 * * * \\
(8.66)\end{array}$ & & $\begin{array}{r}0.111^{* * *} \\
(8.95)\end{array}$ \\
\hline Obs & 5643 & 5643 & 5643 & 5643 & 5643 & 5643 & 5616 & 5616 \\
\hline
\end{tabular}

Source: Authors.

Note: *, ${ }^{* *}$ and ${ }^{* * *}$ indicate the significance levels of $10 \%, 5 \%$ and $1 \%$, respectively.

The sample size differences between HP and the other models are due to the lagged variable used in HP. It is worth mentioning that $\tau$ parameters are found only in Durbin models (SDM models) and that, in column 7 (Table 3), $\rho$ is very close to zero, indicating that the indirect effects in HP-SAR will also be very close to zero. Hence, we drop these results in Table 4. 
The direct effects of HP-SDM, since there is no $\rho$, are -2.583 (ethanol price) and 3.426 (gasoline price). The indirect effects in this case are in the second part of Table $3,-0.271$ (ethanol) and 0.109 (gasoline). The total effects are the sum of the indirect and direct effects, so, for gasoline, we have a direct effect of 3.426, an indirect effect of 0.109 and a total effect of 3.426+0.109. The $\Phi$ parameters estimated in HP-SAR and HP-SDM are around 0.5 (Table 3), suggesting that the long-run effects are double the short-run effects.

Both HP estimators used for the ethanol demand seem to overestimate the price and cross-price elasticities, even considering that other studies have indicated an increase in these. Some attempts are made in the direction of determining whether the unit roots play a role in these results, using Hodrick-Prescott filter prices, but the estimates of own-price elasticity in the ethanol demand are consistently between 3 and 4 .

As previously mentioned, only the parameters found in OLS and GLS are immediately interpreted as marginal effects. Hence, the marginal effects for estimators 3-6 are presented in Table 4.

Table 4 Marginal effects for the ethanol demand (long run)

\begin{tabular}{lrrrrr}
\hline & $\mathbf{( 3 )}$ & $\mathbf{( 4 )}$ & $\mathbf{( 5 )}$ & $\mathbf{( 6 )}$ \\
\hline & SAR-FE & SAR-RE & SDM-FE & SDM-RE \\
\hline Direct & & & & \\
\hline Pe & $-3.084^{* * *}$ & $-3.089^{* * *}$ & $-3.099^{* * *}$ & $-3.095^{* * *}$ \\
\hline Fleet & $3.750^{* * *}$ & $3.746^{* * *}$ & $5.446^{* * *}$ & $5.434^{* * *}$ \\
\hline Income & $0.950^{* * *}$ & $0.950^{* * *}$ & $1.187^{* * *}$ & $1.197^{* * *}$ \\
\hline Indirect & $0.239^{* * *}$ & $0.240^{* * *}$ & 0.0668 & 0.0710 \\
\hline Pe & & & \\
\hline Pg & $-1.596^{* * *}$ & $-1.571^{* * *}$ & $-0.676^{* * *}$ & $-0.633^{* * *}$ \\
\hline Fleet & $1.941^{* * *}$ & $1.905^{* * *}$ & $-1.494^{* * *}$ & $-1.591^{* * *}$ \\
\hline Income & $0.492^{* * *}$ & $0.483^{* * *}$ & $-0.383^{* * *}$ & $-0.391^{* * *}$ \\
\hline Total & $0.124^{* * *}$ & $0.122^{* * *}$ & $0.918^{* * *}$ & $0.867^{* * *}$ \\
\hline Pe & & & \\
\hline Pg & $-4.679^{* * *}$ & $-4.661^{* * *}$ & $-3.774^{* * *}$ & $-3.727^{* * *}$ \\
\hline Fleet & $5.691^{* * *}$ & $5.651^{* * *}$ & $3.952^{* * *}$ & $3.843^{* * *}$ \\
\hline Income & $1.442^{* * *}$ & $1.433^{* * *}$ & $0.804^{* * *}$ & $0.806^{* * *}$ \\
\hline So & $0.363^{* * *}$ & $0.361^{* * *}$ & $0.985^{* * *}$ & $0.938^{* * *}$ \\
\hline
\end{tabular}

Source: Authors.

Note: ${ }^{*},{ }^{* *}$ and ${ }^{* * *}$ indicate the significance levels of $10 \%, 5 \%$ and $1 \%$, respectively. 
The cross-price elasticity indicates that the ethanol demand is as sensitive to gasoline prices as to its own prices. This suggests that policies that aim to change the ethanol demand could efficiently target either of the two fuels.

The marginal effect of the number of vehicles, or "fleet elasticity", represents the demand sensitivity to changes in the number of vehicles. This total effect is between 0.8 and 1.4, considering specifications 3-6 from Table 4.

Table 5 Estimates for the gasoline demand

\begin{tabular}{|c|c|c|c|c|c|c|c|c|}
\hline & (1) & (2) & (3) & (4) & (5) & (6) & (7) & (8) \\
\hline & OLS & GLS & SAR-FE & SAR-RE & SDM-FE & SDM-RE & HP-SAR & HP-SDM \\
\hline$\Phi\left(Y_{t-1}\right)$ & & & & & & & $\begin{array}{r}0.102^{* * *} \\
(3.84)\end{array}$ & $\begin{array}{r}0.061^{* *} \\
(2.45)\end{array}$ \\
\hline $\mathrm{Pe}$ & $\begin{array}{r}0.462^{* * *} \\
(20.90)\end{array}$ & $\begin{array}{r}0.0797^{*} \\
(2.54)\end{array}$ & $\begin{array}{r}0.208^{* * *} \\
(11.00)\end{array}$ & $\begin{array}{r}0.208^{* * *} \\
(10.99)\end{array}$ & $\begin{array}{r}0.512 * * * \\
(24.87)\end{array}$ & $\begin{array}{r}0.505 * * * \\
(24.52)\end{array}$ & $\begin{array}{r}0.282 * * * \\
(14.04)\end{array}$ & $\begin{array}{r}0.308^{* * *} \\
(12.91)\end{array}$ \\
\hline $\mathrm{Pg}$ & $\begin{array}{r}-0.782^{* * *} \\
(-28.10)\end{array}$ & $\begin{array}{r}-0.536^{* * *} \\
(-12.74)\end{array}$ & $\begin{array}{r}-0.767^{* * *} \\
(-25.73)\end{array}$ & $\begin{array}{r}-0.766^{* * *} \\
(-25.67)\end{array}$ & $\begin{array}{r}-0.877^{* * *} \\
(-25.10)\end{array}$ & $\begin{array}{r}-0.880^{* * * *} \\
(-25.15)\end{array}$ & $\begin{array}{r}-0.965 * * * \\
(-33.64)\end{array}$ & $\begin{array}{r}-0.832^{* * *} \\
(-23.21)\end{array}$ \\
\hline Fleet & $\begin{array}{r}0.550^{* * * *} \\
(69.43)\end{array}$ & $\begin{array}{r}0.625^{* * *} \\
(59.71)\end{array}$ & $\begin{array}{r}0.390^{* * *} \\
(42.04)\end{array}$ & $\begin{array}{r}0.392^{* * *} \\
(42.10)\end{array}$ & $\begin{array}{r}0.824^{* * *} \\
(70.46)\end{array}$ & $\begin{array}{r}0.815^{* * *} \\
(70.26)\end{array}$ & $\begin{array}{r}0.483^{* * *} \\
(53.36)\end{array}$ & $\begin{array}{r}0.563^{* * *} \\
(51.74)\end{array}$ \\
\hline Income & $\begin{array}{r}0.350^{* * * *} \\
(44.08)\end{array}$ & $\begin{array}{r}0.247^{* * *} \\
(23.73)\end{array}$ & $\begin{array}{r}0.147^{* * *} \\
(12.41)\end{array}$ & $\begin{array}{r}0.152^{* * *} \\
(12.77)\end{array}$ & $\begin{array}{r}0.166^{* * *} \\
(15.92)\end{array}$ & $\begin{array}{r}0.161^{* * *} \\
(15.64)\end{array}$ & $\begin{array}{r}0.221 * * * \\
(18.42)\end{array}$ & $\begin{array}{r}0.161^{* * *} \\
(12.38)\end{array}$ \\
\hline Const & $\begin{array}{r}0.882^{* * *} \\
(22.88) \\
\end{array}$ & $\begin{array}{r}1.039^{* * *} \\
(16.13)\end{array}$ & & $\begin{array}{r}2.429^{* * *} \\
(17.16) \\
\end{array}$ & & $\begin{array}{r}1.797^{* * *} \\
(16.02) \\
\end{array}$ & $\begin{array}{r}2.799 * * * \\
(30.29)\end{array}$ & \\
\hline$\rho$ & & & $\begin{array}{r}0.248^{* * *} \\
(23.76) \\
\end{array}$ & $\begin{array}{r}0.243^{* * *} \\
(23.13) \\
\end{array}$ & $\begin{array}{r}0.580^{* * *} \\
(56.63) \\
\end{array}$ & $\begin{array}{r}0.580^{* * *} \\
(56.65) \\
\end{array}$ & $\begin{array}{r}0.007^{* * *} \\
(8.46) \\
\end{array}$ & \\
\hline$\tau$ & & & & & & & & \\
\hline $\mathrm{Pe}$ & & & & & $\begin{array}{r}-0.304^{* * *} \\
(-12.83)\end{array}$ & $\begin{array}{r}-0.299 * * * \\
(-12.64)\end{array}$ & & $\begin{array}{r}0.024^{* * *} \\
(-3.24)\end{array}$ \\
\hline $\mathrm{Pg}$ & & & & & $\begin{array}{r}0.305^{* * *} \\
(7.44)\end{array}$ & $\begin{array}{r}0.315 * * * \\
(7.68)\end{array}$ & & $\begin{array}{r}-0.080^{* * *} \\
(-8.93)\end{array}$ \\
\hline Fleet & & & & & $\begin{array}{r}-0.663^{* * *} \\
(-46.99)\end{array}$ & $\begin{array}{r}-0.655^{* * *} \\
(-46.83)\end{array}$ & & $\begin{array}{r}-0.042^{* * *} \\
(-12.72)\end{array}$ \\
\hline Income & & & & & $\begin{array}{r}-0.0494^{* * *} \\
(-3.62) \\
\end{array}$ & $\begin{array}{r}-0.0402^{* *} \\
(-2.94) \\
\end{array}$ & & $\begin{array}{r}0.051^{* * *} \\
(12.55) \\
\end{array}$ \\
\hline Obs & 5643 & 5643 & 5643 & 5643 & 5643 & 5643 & 5616 & 5616 \\
\hline
\end{tabular}

Source: Authors.

Note: ${ }^{*},{ }^{* *}$ and ${ }^{* *}$ indicate the significance levels of $10 \%, 5 \%$ and $1 \%$, respectively.

The income elasticities are around 0.3 in the long run, considering only the SAR and HP estimators. Among the three most researched elasticities 
in this market (own-price, cross-price and income), the last one has the largest range of results in the literature, varying from 0.14 in the study by SANTOS and FARIA (2012) to 12.76 in the one by RANDOW et al. (2010). This large variation can be justified by the different proxies used for income (per capita GDP in cross-sectional studies and electricity and taxes in panel data studies). It seems that part of the income effect is naturally captured by the fleet increases. If we drop the fleet from the regressions, the ethanol demand becomes income elastic, with elasticities around 1.3.

The parameters for the gasoline demand are in Table 5. The explanatory variables used to estimate the gasoline demand are the same as those for the ethanol demand, with the exception of the variable "fleet-g", which is used instead of "fleet-e".

Table 6 Marginal effects for the gasoline demand (long run)

\begin{tabular}{lrrrrr}
\hline & $\mathbf{( 3 )}$ & $\mathbf{( 4 )}$ & $\mathbf{( 5 )}$ & $\mathbf{( 6 )}$ \\
\cline { 2 - 5 } Direct & SAR-FE & SAR-RE & SDM-FE & SDM-RE \\
\hline $\mathrm{Pe}$ & $0.212^{* * *}$ & $0.212^{* * *}$ & $0.511^{* * *}$ & $0.504^{* * *}$ \\
\hline $\mathrm{Pg}$ & $-0.783^{* * *}$ & $-0.782^{* * *}$ & $-0.925^{* * *}$ & $-0.927^{* * *}$ \\
\hline Fleet & $0.398^{* * *}$ & $0.399^{* * *}$ & $0.783^{* * *}$ & $0.774^{* * *}$ \\
\hline Income & $0.149^{* * *}$ & $0.154^{* * *}$ & $0.176^{* * *}$ & $0.173^{* * *}$ \\
\hline Indirect & & & & \\
\hline Pe & $0.0647^{* * *}$ & $0.0631^{* *}$ & -0.0147 & -0.0120 \\
\hline Pg & $-0.239^{* * *}$ & $-0.233^{* * *}$ & $-0.436^{* * *}$ & $-0.420^{* * *}$ \\
\hline Fleet & $0.122^{* * *}$ & $0.119^{* * *}$ & $-0.399^{* * *}$ & $-0.394^{* * *}$ \\
\hline Income & $0.0455^{* * *}$ & $0.0458^{* * *}$ & $0.0999^{* * *}$ & $0.116^{* * *}$ \\
\hline Total & & & & \\
\hline Pe & $0.277^{* * *}$ & $0.275^{* * *}$ & $0.497^{* * *}$ & $0.492^{* * *}$ \\
\hline Pg & $-1.022^{* * *}$ & $-1.014^{* * *}$ & $-1.361^{* * *}$ & $-1.347^{* * *}$ \\
\hline Fleet & $0.520^{* * *}$ & $0.518^{* * *}$ & $0.384^{* * *}$ & $0.380^{* * *}$ \\
\hline Income & $0.194^{* * *}$ & $0.200^{* * *}$ & $0.276^{* * *}$ & $0.288^{* * *}$ \\
\hline
\end{tabular}

Source: Authors.

Note: * ** and ${ }^{* * *}$ indicate the significance levels of $10 \%, 5 \%$ and $1 \%$, respectively.

For the gasoline demand, it is also necessary to calculate the marginal effects. However, it is important to state that parameters $\rho$ and $\Phi$ in HP-SAR are very close to zero, indicating that the differences between direct and 
indirect effects and between short-run and long-run effects will both be very small. Hence, we can interpret column 7 in Table 5 as the long-run total effects of HP-SAR. The same logic can be applied to HP-SDM: all the indirect effects (measured with the interaction between $\tau$ and elasticities) are significant but very close to zero. Therefore, we report in Table 6 only the marginal effects of estimators 3-6 from Table 5, excluding HP-SAR and HP-SDM.

The price elasticity of the gasoline demand is between -1.0 and -1.3 , indicating that a change of $1 \%$ in the price will be followed by a reduction in consumption from $1.0 \%$ to $1.3 \%$. The cross-price elasticities also have the expected signal (positive), with values that are approximately one-third of the gasoline price. Hence, changes in gasoline prices will have three times greater impact than changes in ethanol prices, in line with MORIZONO et al. (2018).

The marginal effect of the number of vehicles is lower than one in the long run. This result could be caused by the fuel economy of the new cars or by different consumption profiles of the owners of the marginal cars. With respect to the income elasticity, the results indicate that gasoline is a normal good with income elasticity around 0.2 . The results are lower than the previous estimates of income elasticity, but, again, there is a large range of estimates due to the use of different proxies.

The results also indicate that both demands have higher sensitivity to the gasoline price than to the ethanol price. If a policy goal is to change the demanded quantity, this result suggests that the gasoline price is the factor on which the policy should focus. On the other hand, if the government's objective is to increase the tax revenue, the focus should be on the ethanol price.

When looking at future increases in the demand for light fuels, the results indicate that, ceteris paribus, increases in the number of vehicles or in income have a greater effect on the ethanol demand than the gasoline demand. These results come from the comparison between ethanol and gasoline long-run "fleet" elasticities and income elasticities.

The last part of the study comprehended tests to check whether the results are sensitive to a prior specification of the $\mathrm{W}$ matrix. The $\mathrm{W}$ matrix defined here needs to be symmetric, ${ }^{13}$ containing 729 elements $(27 \times 27)$. The first kind of matrix used is a Queen-1 (Q1). In $\mathrm{Q} 1, \mathrm{Wij}=1$ if states 
share a common edge with each other and 0 otherwise. With Queen-2, $\mathrm{Wij}=1$ for the neighbours and for the regions that border the neighbours. There are also Queen-3 and Queen-4 matrices, but, since there are only 27 states in Brazil, it does not make sense to use matrices of orders higher than 2. The inverse distance matrix (ID) and some K-nearest neighbour matrices $(\mathrm{K}=5,4$ and 3 ) are also used. For each given $\mathrm{K}$, the $\mathrm{K}$-nearest neighbour will have a value equal to 1 , while the more distant units will equal $0 .{ }^{14}$

Using the same estimator (SAR-FE), we change only the matrices and report the marginal total effects in Table 7.

Table 7 Sensitivity to W choice

\begin{tabular}{lr|r|r|r|r|r}
\hline & Queen-1 & Queen-2 & ID & Near-5 & Near-4 & Near-3 \\
\hline \multirow{2}{*}{ Pe } & $0.277^{* * *}$ & $0.281^{* * *}$ & $0.242^{* * *}$ & $0.240^{* * *}$ & $0.234^{* * *}$ & $0.224^{* * *}$ \\
& $(10.99)$ & $(10.95)$ & $(9.75)$ & $(7.93)$ & $(8.06)$ & $(7.78)$ \\
\hline \multirow{2}{*}{ Pg } & $-1.022^{* * *}$ & $-1.004^{* * *}$ & $-0.977^{* * *}$ & $-1.024^{* * *}$ & $-0.994^{* * *}$ & $-0.949^{* * *}$ \\
& $(-28.83)$ & $(-27.69)$ & $(-27.99)$ & $(-24.12)$ & $(-24.34)$ & $(-23.40)$ \\
\hline \multirow{2}{*}{ Income } & $0.197^{* * *}$ & $0.219^{* * *}$ & $0.194^{* * *}$ & $0.209^{* * *}$ & $0.203^{* * *}$ & $0.182^{* * *}$ \\
& $(13.37)$ & $(14.59)$ & $(13.52)$ & $(11.81)$ & $(11.97)$ & $(10.85)$ \\
\hline \multirow{2}{*}{ Fleet } & $0.518^{* * *}$ & $0.505^{* * *}$ & $0.526^{* * *}$ & $0.521^{* * *}$ & $0.529^{* * *}$ & $0.559^{* * *}$ \\
& $(49.23)$ & $(47.68)$ & $(50.68)$ & $(41.49)$ & $(43.71)$ & $(45.85)$ \\
\hline $\boldsymbol{N}$ & 5643 & 5643 & 5643 & 5643 & 5643 & 5643 \\
\hline
\end{tabular}

Source: Authors.

Note: ${ }^{*},{ }^{*}$ and ${ }^{* * *}$ indicate the significance levels of $10 \%, 5 \%$ and $1 \%$, respectively.

As Table 7 shows, the results obtained using different spatial matrices are close. Only the SAR model is applied to the gasoline demand, and the lack of sensitivity to the W choice, as LESAGE and PACE (2011) argued, is confirmed.

\section{Conclusions}

For both demands (gasoline and ethanol), the tests using OLS residuals indicated cross-sectional dependence (CD). To solve this problem, two dif-

14 Rook matrices and queen matrices have exactly the same results, since, in the present study, they represent exactly the same matrices. Therefore, only the queen matrix results are reported. 
ferent procedures were carried out: GLS with $A R(1)$ and estimators for CD correction, which is efficient whenever there is $\mathrm{CD}$, and a spatial queen matrix (W), which makes it possible to capture non-observed effects that are responsible for such dependence. Although these strategies achieved better results than the standard OLS, both failed to reject the null hypothesis of the Breusch-Pagan (BP) test. ${ }^{15}$

There were no surprises with the parameters: the own-price elasticity was negative, and the cross-price, income and "fleet" elasticities were positive. The results also indicated higher long-run parameters than shortrun ones for the ethanol demand, while, for the gasoline demand, the differences between short- and long-run parameters were insignificant.

The results also indicated that the ethanol demand is price and crossprice inelastic in the short and long runs, in line with the Brazilian empirical literature (Table A - Appendix). The gasoline demand is less sensitive to prices than the ethanol demand, which might suggest that higher volatility can be expected in the ethanol market.

The ethanol parameters were more elastic than the gasoline parameters, considering the fleet and income parameters. Hence, increases in fleet or income have a greater impact on the ethanol demand than on the gasoline demand. Even though LESAGE and PACE (2012) claimed that the sensitivity of marginal effects to the neighbourhood matrix (W) is a myth in spatial econometrics, other specifications of $\mathrm{W}$ were tested and the results indicated that our estimates did not present high sensitivity to this choice.

The literature regarding spatial econometrics is still expanding, and it is expected that more accurate tests will be available to identify individual effects in panels with CD. It is important to highlight our novelty of including dynamic spatial estimators for the light fuel market in Brazil. However, the dynamics among variables here were still limited, and the ratio between short- and long-run effects was the same for all the explanatory variables. If $\Phi$ was 0.5 , for example, the values of the long-run parameters would be double those of the short-run parameters for all the variables, but there is no theoretical or empirical guarantee for that.

The use of ethanol as an alternative fuel in the medium run is reasonable in producing states, but distance (and logistics) could be a problem. 15 SEN and BERA (2011) have already reported possible over rejection of the BP test in panels with the presence of $\mathrm{CD}$. 
However, higher productivity gains are expected for ethanol than for gasoline due to the differences in their learning curves.

\section{References}

AGÊNCIA NACIONAL DE PETRÓLEO, GÁS NATURAL E BIOCOMBUSTÍVEIS (ANP). Ministério de Minas e Energia, Brasil. Sistema de Levantamento de Preços. Disponível em: http://www.anp.gov.br/.

ALMEIDA, E. T. de et al. Uma análise da demanda por combustíveis através do modelo almost ideal demand system para Pernambuco. Revista de Economia e Sociologia Rural, v. 54, n. 4, p. 691-708, 2016.

ALMEIDA, E. Econometria espacial. Campinas, SP: Alínea, 2012.

ALVES, D. C. O.; BUENO, R. D. L. D. S. Short-run, long-run and cross elasticities of gasoline demand in Brazil. Energy Economics, v. 25, n. 2, p. 191-199, 2003.

ANSELIN, L.; LE GALLO, J.; JAYET, H. Spatial panel econometrics. In: The econometrics of panel data. Berlin, Heidelberg: Springer, 2008. p. 625-660.

BASSO, L. J.; Oum, T. H. Automobile fuel demand: a critical assessment of empirical methodologies. Transport Reviews, v. 27, n. 4, p. 449-484, 2007.

BRANNAN, M. Examining the short-run price elasticity of gasoline demand in the United States. 2012.

BRASIL. Petroleum Law. Lei n 9.478. 6 August 1997.

BREUSCH, T.; PAGAN, A. The Lagrange multiplier test and its applications to model specification in econometrics. Review of Economic Studies, v. 47, p. 239-253, 1980.

BRITISH PETROLEUM. BP statistical review of world energy. British Petroleum, 2018.

BRONS, M. et al. A meta-analysis of the price elasticity of gasoline demand. A SUR approach. Energy Economics, v. 30, n. 5, p. 2105-2122, 2008.

BURNQUIST, H. L.; BACCHI, M. R. P. A demanda por gasolina no Brasil: uma análise utilizando técnicas de co-integração. In: XL CONGRESSO BRASILEIRO DE ECONOMIA E SOCIOLOGIA RURAL 2002. Passo Fundo, RS: Equidade e Eficiência na Agricultura Brasileira, 2002.

BURRIDGE, P. On the Cliff-Ord test for spatial correlation. Journal of the Royal Statistical Society: Series B (Methodological), v. 42, n. 1, 107-108, 1980.

CARDOSO, L. C. B. et al. Biofuels policies and fuel demand elasticities in Brazil. Energy Policy, v. 128, p. 296-305, 2019.

CARDOSO, L. C. B.; BITTENCOURT, M. V. L. Elasticidades da demanda de curto e longo prazo por etanol no Brasil no período de 2001 a 2011: um estudo utilizando painéis cointegrados. In: XL ENCONTRO NACIONAL DE ECONOMIA - 2012. 2012.

CHEUNG, K.-Y.; THOMSON, E. The demand for gasoline in China: a cointegration analysis. Journal of Applied Statistics, v. 31, n. 5, p. 533-544, 2004. 
CORRADO, L.; FINGLETON, B. Where is the economics in spatial econometrics? Journal of Regional Science, v. 52, n. 2, p. 210-239, 2012.

DAHL, C.; STERNER, T. Analysing gasoline demand elasticities: a survey. Energy Economics, v. 13, n. 3, p. 203-210, 1991.

DEBARSY, N.; ERTUR, C.; LESAGE, J. P. Interpreting dynamic space-time panel data models. Statistical Methodology, v. 9, n. 1-2, p. 158-171, 2012.

ELHORST, J. P. Dynamic spatial panels: models, methods and inferences. In: Spatial econometrics. Berlin, Heidelberg: Springer, 2014. p. 95-119.

ESPEY, M. Gasoline demand revisited: an international meta-analysis of elasticities. Energy Economics, v. 20, n. 3, p. 273-295, 1998.

FARINA, E. M. M. Q. et al. Mercado e concorrência do etanol. Etanol e Bioeletricidade: a cana-de-açúcar no future da matriz energética, v. 1, p. 23-36, 2010.

FINGLETON, B. A generalized method of moments estimator for a spatial panel model with an endogenous spatial lag and spatial moving average errors. Spatial Economic Analysis, v. 3, n. 1, p. 27-44, 2008.

FINGLETON, B.; ARBIA, G. New spatial econometric techniques and applications in regional science. Papers in Regional Science, v. 87, n. 3, p. 311-317, 2008.

FREITAS, L. C. de; KANEKO, S. Ethanol demand under the flex-fuel technology regime in Brazil. Energy Economics, v. 33, n. 6, p. 1146-1154, 2011.

GOLDEMBERG, J.; GUARDABASSI, P. The potential for first-generation ethanol production from sugarcane. Biofuels, Bioproducts and Biorefining: Innovation for a Sustainable Economy, v. 4, n. 1, p. 17-24, 2010.

GOMEZ, J. M. A.; LEGEY, L. F. L. An analysis of the impact of flex-fuel vehicles on fuel consumption in Brazil, applying cointegration and the Kalman filter. Energy, v. 81, p. 696-705, 2015.

GOODWIN, P.; DARGAY, J.; HANLY, M. Elasticities of road traffic and fuel consumption with respect to price and income: a review. Transport Reviews, v. 24, n. 3, p. 275-292, 2004.

HAN, C.; PHILLIPS, P. C. B. GMM estimation for dynamic panels with fixed effects and strong instruments at unity. Econometric Theory, v. 26, n. 1, p. 119-151, 2010.

HUGHES, J.; KNITTEL, C. R.; SPERLING, D. Evidence of a shift in the short-run price elasticity of gasoline demand. Energy Journal, v. 29, n. 1, 2008.

HUNTINGTON, H. G.; BARRIOS, J. J.; ARORA, V. Review of key international demand elasticities for major industrializing economies. Energy Policy, v. 133, p. 110878, 2019.

LESAGE, J. P.; KELLEY PACE, R. Pitfalls in higher order model extensions of basic spatial regression methodology. Review of Regional Studies, v. 41, n. 1, p. 13-26, 2011.

LIM, K.-M.; YOO, S.-H. Short-run and long-run elasticities of gasoline demand: the case of Korea. Energy Sources, Part B: Economics, Planning, and Policy, v. 11, n. 5, p. 391-395, 2016.

MITSUTANI, C. A logística do etanol de cana-de-açúcar no Brasil: condicionantes e perspectivas. Diss. Universidade de São Paulo, São Paulo, 2010.

MORIZONO, R. C.; RAMOS, H. R.; KNIESS, C. T. Análise da preferência de consumidores por etanol e gasolina no Brasil. Ensaios FEE, v. 38, n. 4, p. 877-902, 2018. 
NAPPO, M. A demanda por gasolina no Brasil: uma avaliação de suas elasticidades após a introdução dos carros bicombustíveis. Diss. Fundação Getúlio Vargas, São Paulo, 2007.

NARDY, V.; GURGEL, A. C. Impactos da liberalização do comércio de etanol entre Brasil e Estados Unidos sobre o uso da terra e emissão de CO2. Nova Economia, v. 23, n. 3, p. 693-726, 2013.

PESARAN, M. H. General diagnostic tests for cross section dependence in panels. Discussion Paper at IZA DP, n. 1240, Bonn, Germany, 2004.

PESARAN, M. H. A simple panel unit root test in the presence of cross-section dependence. Journal of Applied Econometrics, v. 22, n. 2, p. 265-312, 2007.

POCK, M. Gasoline and diesel demand in Europe: new insights. Energy Economics, Elsevier, vol. 32 (1), p. 54-62, 2010.

PRAIS, S. J.; WINSTEN, C. B. Trend estimators and serial correlation. Discussion Paper. Vol. 383. Chicago: Cowles Commission, 1954.

RAMANATHAN, R. Short-and long-run elasticities of gasoline demand in India: an empirical analysis using cointegration techniques. Energy Economics, v. 21, n. 4, p. 321-330, 1999.

RANDOW, B. M. V.; FONTES, R. M. O; CARMINATI, J. G. de O. Estimativas das elasticidades-preço e renda da demanda por álcool combustível no Brasil. In: $48^{\circ}$ Congresso da Sociedade Brasileira de Economia Administração e Sociologia Rural. 2010.

RODRIGUES, L.; BACCHI, M. R. P. Light fuel demand and public policies in Brazil, 20032013. Applied Economics, v. 48, n. 54, p. 5300-5313, 2016.

RODRIGUES, N.; LOSEKANN, L.; FILHO, G. S. Demand of automotive fuels in Brazil: underlying energy demand trend and asymmetric price response. Energy Economics, v. 74, p. 644-655, 2018.

ROPPA, B. F. Evolução do consumo de gasolina no Brasil e suas elasticidades: 1973 a 2003. Monografia De Bacharelado, Universidade Federal Do Rio De Janeiro, Instituto De Economia, 2005. p. 23.

SALVINI, R. R.; BURNQUIST, H. L.; JACOMINI, R. L. Investigando a assimetria na transmissão dos preços dos combustíveis no Estado de São Paulo. Anais do Seminário Científico do UNIFACIG 2, 2017.

SANTOS, G. F. Fuel demand in Brazil in a dynamic panel data approach. Energy Economics, v. 36, p. 229-240, 2013.

SANTOS, G. Dos; FARIA, W. Spatial panel data models and fuel demand in Brazil. TD Nereus, 2012.

SCHÜNEMANN, L. A demanda de gasolina automotiva no Brasil: o impacto nas elasticidades de curto e longo prazo da expansão do GNV e dos carros flex. 107p. Dissertação de Mestrado. Faculdades de Economia e Finanças do Ibmec. Rio de Janeiro: Faculdades Ibmec, 2007.

SEN, M. Three essays in spatial econometrics. Diss. University of Illinois at Urbana-Champaign, 2012.

SEN, M.; Bera, A. K. Specification testing for panel spatial models. Working Paper. Version: July 2011. University of Illinois at Urbana Champaign, 2011.

SERIGATI, F. C.; CORREIA, L. B.; PEROSA, B. B. O impacto dos veículos flex-fuel sobre o 
mercado de combustíveis no Brasil. In: XLVIII Congresso Brasileiro de Economia, Administração e Sociologia Rural, 2010, Tecnologias, Desenvolvimento e Integração Social. 2010.

SOUZA, A. de N. de. Estudo das demandas de etanol e gasolina no Brasil no período 2001-2009.

Diss. Fundação Getúlio Vargas, Escola de Economia de São Paulo. São Paulo, 2010.

\section{About the authors}

Leonardo C. B. Cardoso-leonardocardoso@ufv.br Federal University of Viçosa, Viçosa, Minas Gerais, Brazil. ORCID: https://orcid.org/0000-0002-5757-107X.

Maurício V.L.Bittencourt-mbittencourt@ufpr.br Federal University of Paraná, Curitiba, Paraná, Brazil. ORCID: https://orcid.org/0000-0002-2858-9043.

Alexandre A.Porsse-porsse@gmail.com

Federal University of Paraná, Curitiba, Paraná, Brazil. ORCID: https://orcid.org/0000-0002-2858-9043.

This study was financed in part by the Coordenação de Aperfeiçoamento de Pessoal de Nível Superior - Brasil (CAPES) and the Conselho Nacional de Desenvolvimento Científico e Tecnológico (CNPq).

\section{About the article}

Submission received on September 18, 2017. Approved for publication on February 04, 2019. 


\section{APPENDIX}

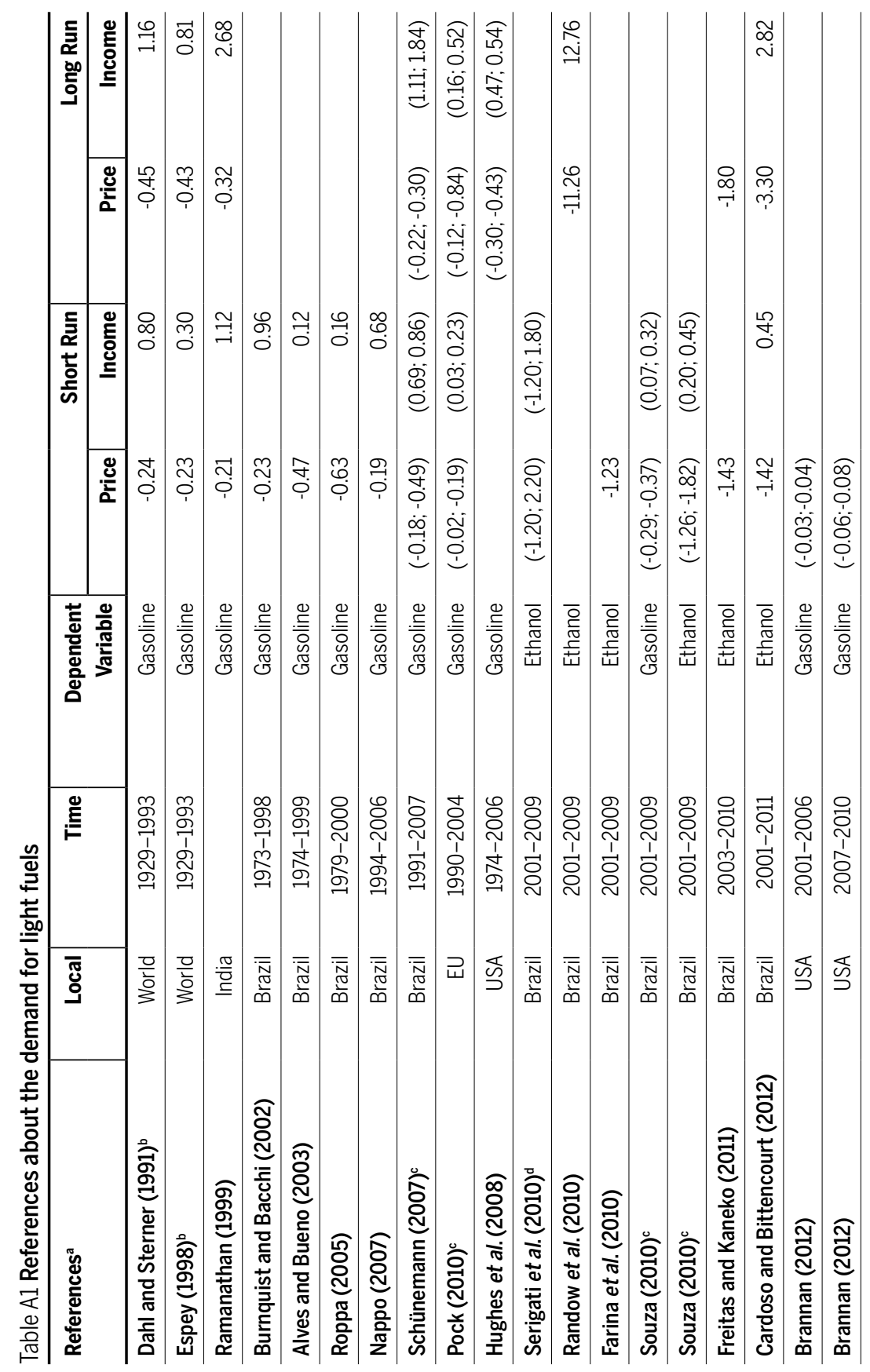




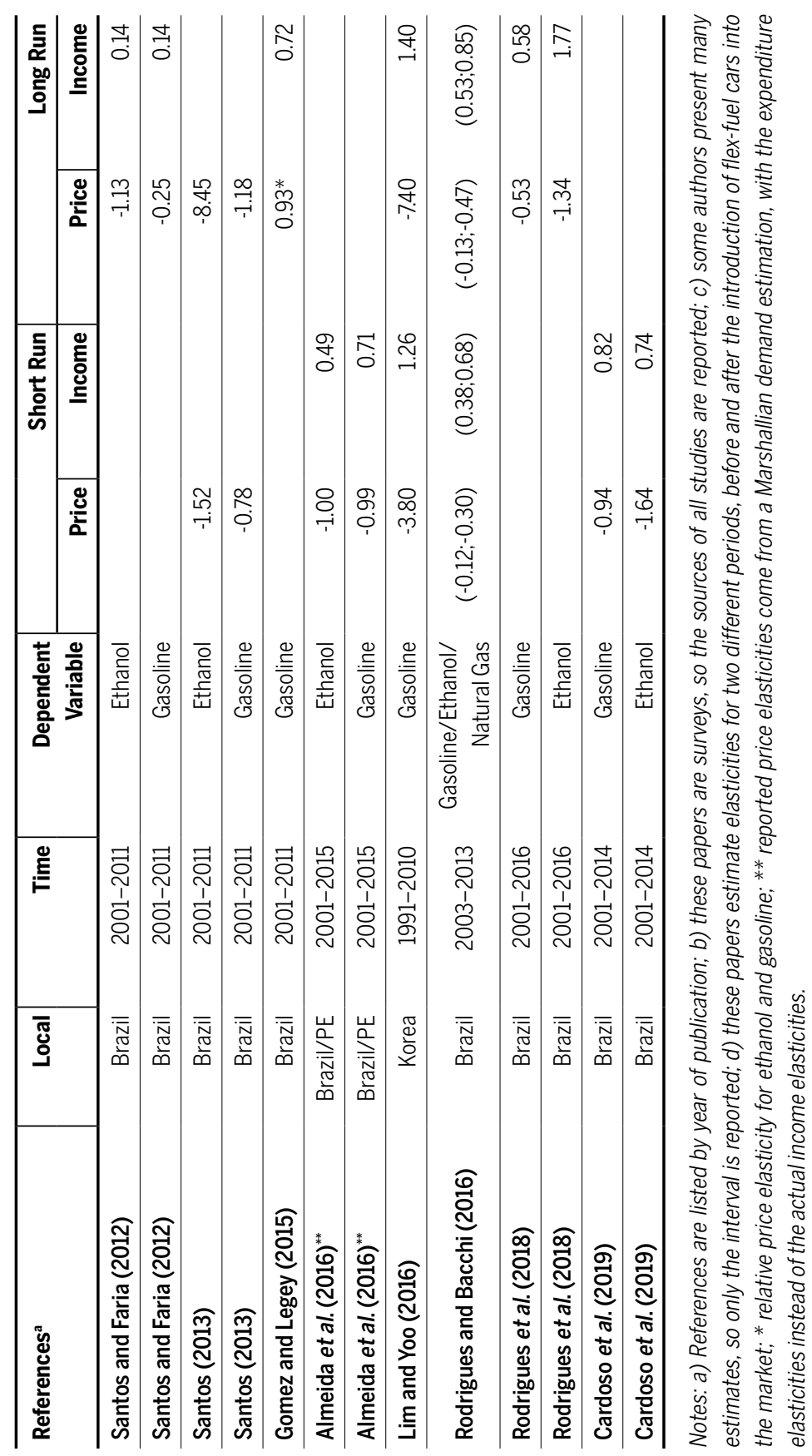

